\title{
The household food budget of the wealthy and the poor in South Africa
}

\author{
J H Martins
}

\section{OPSOMMING}

Die artikel gee 'n uiteensetting van die voedselbegroting van huishoudings in Suid-Afrika volgens inkomstegroepe. Alvorens die besteding aan voedsel bespreek word, word verduidelik wat die minimumvoedselbehoeftes van verskillende tipes huishoudings is volgens die Buro vir Marknavorsing se minimumlewenskostestudies. Hierdie minimum stel die leser in staat om ' $n$ vergelyking te tref met die voedselbegrotings van huishoudings in Suid-Afrika om 'n aanduiding te kry van hoeveel huishoudings onder die broodlyn lewe.

Die minimumvoedselbehoefte word bereken aan die hand van die Departement van Gesondheid se voedselskale vir huishoudings wat in die laagste inkomstegroep val. Die vereiste kilojoules vir die verskillende huishoudingtipes word omgesit in voedselprodukte en die produkte se pryse is opgeneem in die grootste stedelike gebiede van Suid-Afrika.

Besteding aan voedsel van die $20 \%$ armste huishoudings in Suid-Afrika maak $57 \%$ van hulle totale besteding uit terwyl dit $13 \%$ is vir die $20 \%$ rykste huishoudings. Meer as ' $n$ derde (36\%) van die arm huishoudings se voedselbegroting word bestee aan graanprodukte, waarvan mieliemeel, bruin brood en rys die grootste aandeel uitmaak. Byna 'n kwart (24\%) van die rykste $20 \%$ huishoudings se voedselbegroting word bestee aan vleis en vleisprodukte, waaronder bees- en kalfsvleis, pluimvee, skaap- en lamsvleis, boerewors en verwerkte vleis die belangrikste is. Die gemiddelde besteding aan voorbereide voedsel van die rykste groep huishoudings is 138 keer hoër as dié van die armste groep.

Die voedselbegrotings van die $20 \%$ armste en $20 \%$ rykste huishoudings in Suid-Afrika verskil aansienlik. Verder is die voedselbegroting van die $20 \%$ armste huishoudings aansienlik laer as die minimum wat verlang word vir ' $\mathrm{n}$ gesonde lewenstyl terwyl dié van die rykste $20 \%$ hulle toelaat om ' $n$ gesonde dieët te kan handhaaf. Die voedselbestedingspatrone van veral die armste huishoudings hou belangrike implikasies in vir beleidsformulering wat, onder andere, voedselpryse mag beïnvloed.

\section{- Prof Johan H Martins}

Bureau of Market Research UNISA

\section{INTRODUCTION}

Water, food and air are the three main requirements for mankind to live. Scenes of people queuing for food in poverty stricken areas and where natural disasters occur are often portrayed in the media. However, food shortages occur not only in third world countries or countries stricken by disasters but also in first world countries. Bok (2003:37) states that, according to findings of the Department of Agriculture and Community Childhood Hunger Identification project, 4,1 million households and approximately 4 million children under the age of 12 in America go hungry during parts of the year due to insufficient funds. Throughout the world poverty kills over 11 million children annually and malnutrition, one of the most prominent consequences of poverty, is responsible for more than half of these deaths (Talal, 2002:4-5). The Poverty Report of the United Nations Development Programme (UNDP, 2000:20) states that extreme income poverty or absolute poverty is the lack of income to satisfy basic food needs, which are usually defined on the basis of minimum energy requirements.

\section{OBJECTIVES}

The objectives of the article are:

- to determine the food budget according to the minimum living level (MLL) requirements set by the Bureau of Market Research (BMR) at the University of South Africa (Unisa) to serve as a benchmark whereby an indication can be obtained of people living in poverty in South Africa.

- To compare the food budgets of the wealthy and poor to identify the differences in their expenditure patterns.

\section{MINIMUM LIVING LEVEL}

The minimum living level (MLL) denotes the minimum financial requirements of members of a family if they are to maintain their health and have acceptable standards of hygiene and sufficient clothing for their needs (Martins \& Maritz, 2004:1). It also implies that the food budget is spent wisely.

The MLL is the lowest sum possible on which a specific size of family can live in our existing social set-up. There is no such thing as a general or universal living level. In any community a minimum living level would vary from one family to another, depending on its size, the age structure of its members and their gender composition. For this reason the MLL must be calculated for as many different types of families as possi- 


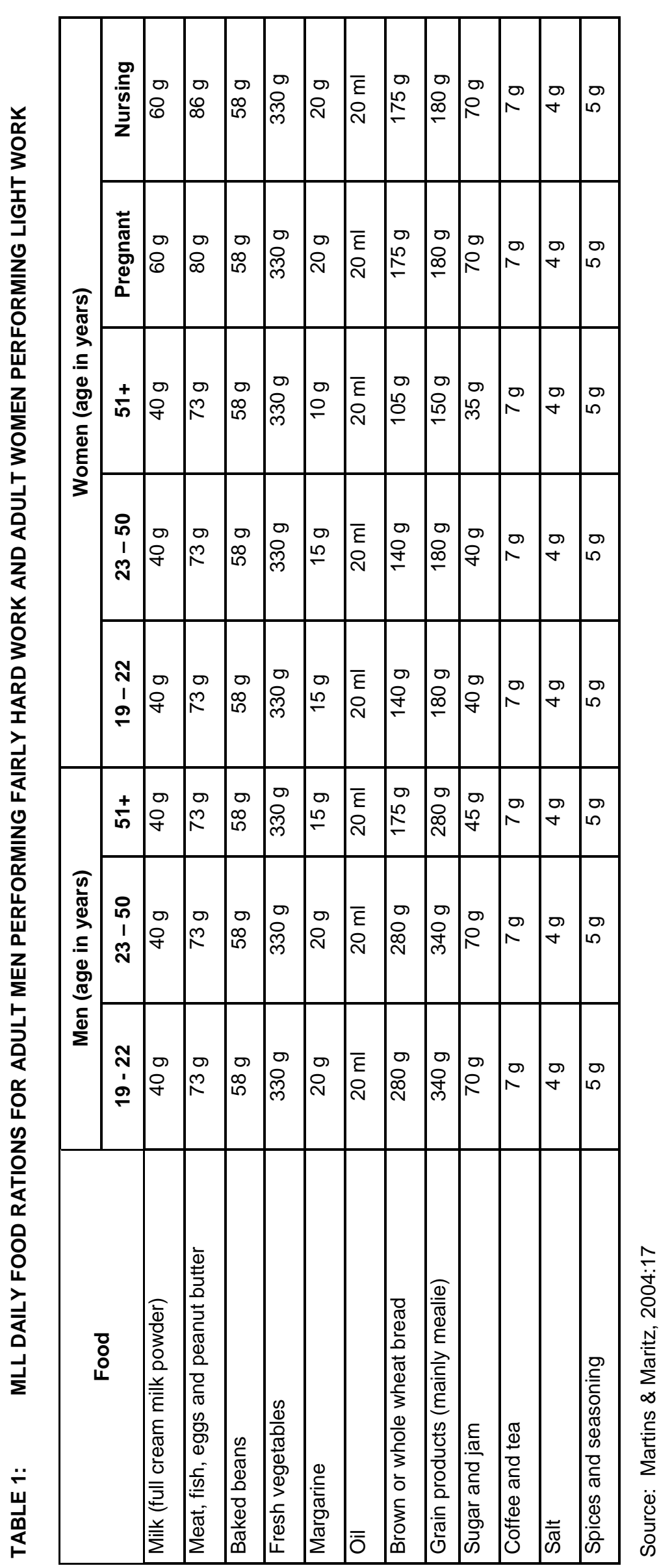




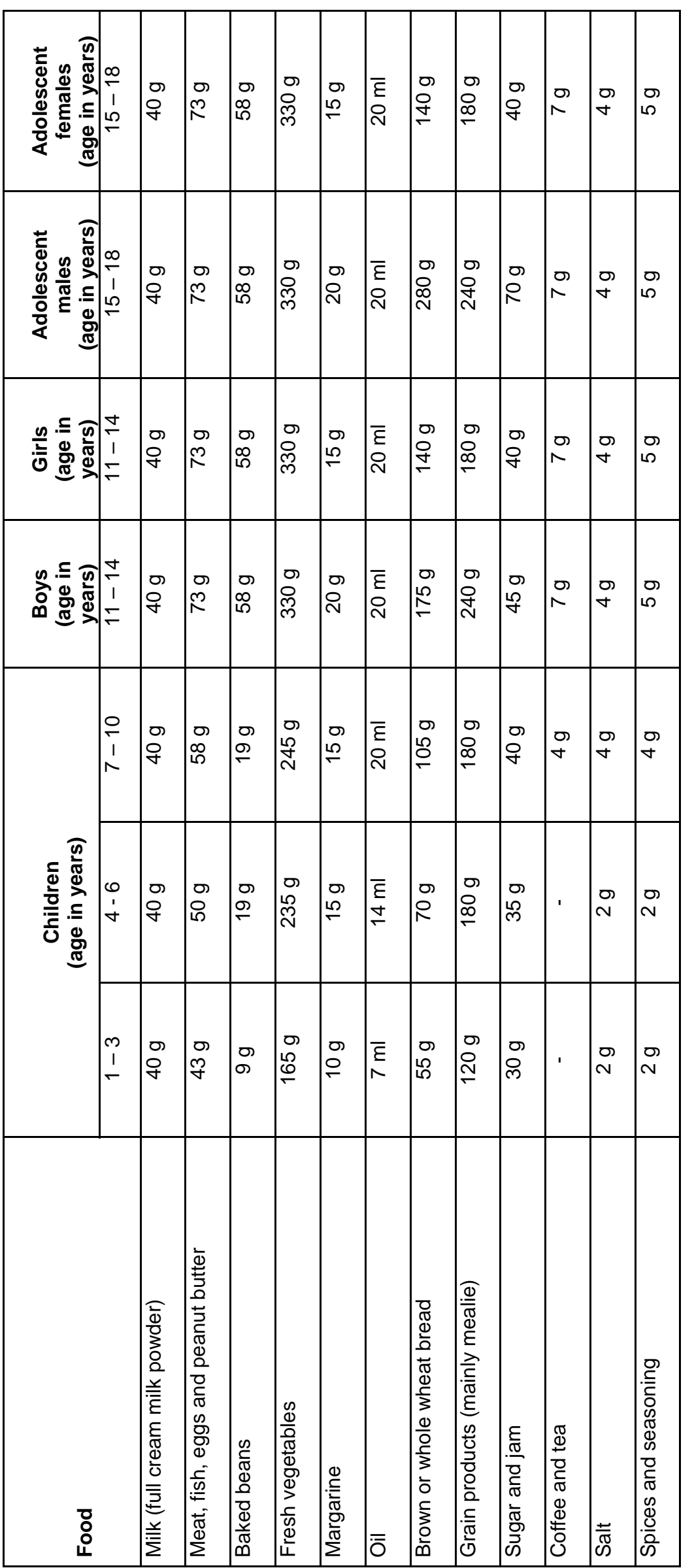

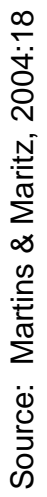


ble. The sum estimated for the MLL is at best a theoretical minimum.

An equivalent of the MLL can be found in the budget standards calculated in Australia, as described by Saunders (2004:1). A budget standard represents what is needed by a particular type of household living in a particular place at a particular time, in order to achieve a particular standard of living. It specifies in great detail the contents of the basket of goods and services required by households of a given structure to achieve the specified standard. The low cost budget standard points towards the same type of calculation as the MLL (Saunders, 2004:23-41).

The following items are included in the calculation of the MLL:

- Food

- Clothing

- Compulsory payments to local authorities in respect of rent, miscellaneous services, water, electricity, etc

- Fuel and light

- Washing and cleaning materials

- Education

- Transport (work, school and shopping)

- Medical and dental expenses, including patent medicine

- Replacement of household equipment and

- Taxes.

The rest of the article will only concentrate on the minimum food requirements.

\section{MLL FOOD REQUIREMENTS}

The daily and weekly food rations allowed were those of the Department of Health (Department of Health and Population Development, 1994) whose food ration scales are based on the American standards recommended by the National Medical Research Council of America. The Department of Health, which is the only official body compiling food ration scales in South Africa, has four different scales for persons in the middle, low-middle, lower and low income brackets (Department of National Health and Population Development, 1994). The MLL financial requirements were calculated using food ration scales for the lowest income group. The scales are set forth in Tables 1 and 2 for men, women and children of various ages. The scales are designed to help the consumer get the best value for his rand, while ensuring a balanced diet.

The department's scales were compiled for persons performing light work which, according to the National Academy of Sciences (1968) comprises the activities as shown in Table 3.

This definition of light work evidently allows for a fair amount of physical exertion. However, the BMR increased the number of kilojoules allowed for working men by $1680 \mathrm{~kJ}$ after consultation with officials of the Department of Health and Population Development, bringing the total to $13000 \mathrm{~kJ}$ (3 100 calories) per
TABLE 3: ACTIVITIES OF A PERSON PERFORMING LIGHT WORK

\begin{tabular}{|l|c|}
\hline \multicolumn{1}{|c|}{ Activity } & Hours \\
\hline Sleeping and reclining & 8 \\
\hline Sitting & 7 \\
\hline Standing & 5 \\
\hline Walking & 2 \\
\hline $\begin{array}{l}\text { Other, including intermittent activities in } \\
\text { occasional sport, exercise, limited stair- } \\
\text { climbing or occupational activities including } \\
\text { light physical work }\end{array}$ & 24 \\
\hline All activities & \\
\hline
\end{tabular}

day. The additional $1680 \mathrm{~kJ}$ were obtained by raising the grain product requirements in Table 1 by $100 \mathrm{~g}$. Grain products are the main staple food of the lower income groups in South Africa, as shown in their expenditure on the main food groups in Table 8. The ratio of eggs, meat, fish and peanut butter (Table 1 ) as well as types of vegetables in a low income diet is shown in Table 4.

The weights in Table 4 are based on the relative mass of the products. The actual mass of the product group, say vegetables, will be determined by the size and structure of the household. The weights in Table 4 will determine the mass of each type of product for a specific household, while the money value is calculated by multiplying the cost per gram for a product type by the required mass.

The number of nursing mothers was regarded as equal to the average number of children under one year, and the number of pregnant women as equal to the number of nursing mothers. The number of women in the 23 to 50 year age group was decreased accordingly. By using the 2001 population census

TABLE 4: RATIO OF EGGS, MEAT, FISH AND PEA-
NUT BUTTER AND TYPES OF VEGENUT BUTTER AND TYPES OF VEGETABLES ALLOWED IN THE MLL DIET

\begin{tabular}{|l|c|c|}
\hline \multicolumn{1}{|c|}{ Type of product } & Mass (gram) & Weight \\
\hline $\begin{array}{l}\text { Eggs, meat, fish and } \\
\text { peanut butter }\end{array}$ & & \\
\hline Eggs & 165 & 0,32 \\
\hline Meat & 180 & 0,35 \\
\hline Fish & 65 & 0,13 \\
\hline Peanut butter & 100 & 0,20 \\
\hline Total & $\mathbf{5 1 0}$ & $\mathbf{1 , 0 0}$ \\
\hline Vegetables & & \\
\hline Pumpkin & 555 & 0,24 \\
\hline Carrots & 210 & 0,09 \\
\hline Potatoes & 485 & 0,21 \\
\hline Tomatoes & 315 & 0,14 \\
\hline Cabbage & 600 & 0,26 \\
\hline Onions & 140 & 0,06 \\
\hline Total & $\mathbf{2 3 0 5}$ & $\mathbf{1 , 0 0}$ \\
\hline
\end{tabular}


data (Stats SA, 2003:28-29) the average household composition in terms of gender and age distribution was calculated for household sizes two to seven and eight plus members for 13 major urban areas. An MLL food budget was calculated for each of these household sizes as well as for an average household size for each of these areas. The money value was obtained by interviewers visiting these areas in March each year and taking prices of food products included in the rations (Tables 1 and 2 ) at various outlets in the central business districts as well as suburbs and townships. The gender profile of households and the MLL food budget by household size is shown in Table 5 .

The average household consists of 3,6 members and the percentage of females increases as household size increases. An average household of 3,6 members consists of $47,5 \%$ males and $52,5 \%$ females. The MLL annual food budget varies from R5 712 for a household of two to R24 060 for a household of eight or more members with R12 804 for an average household in the major urban areas of South Africa in 2004.

\section{HOUSEHOLD BUDGETS BY INCOME GROUP}

An overview of the total household budget of households by income group will be given before concentrating on the food budgets. A household consists of one (a single household) or more persons dependent on a common or pooled income and usually living in the same house and sharing the same table (food budget). The information in the study is based on survey data gathered in a survey conducted by Statistics South Africa (2002), adjusted by the Bureau of Market Research at UNISA (Martins, 2002, 2003 and 2004(a)) and consolidated in a research report by Martins (2004b), entitled Total household expenditure in South Africa by income group, life plane, life stage and product, 2004. Personal face-to-face interviews were conducted using comprehensive pre-structured questionnaires requesting income from approximately 50 sources and expenditure on 550 expenditure items. The total sample for the four surveys mentioned above amounted to 27634 households, representing a total population of 12052518 households in the urban and rural areas of South Africa (Martins, 2004b:46). Table 6 shows the income brackets of the five quintiles as well as the average household sizes.

A total number of approximately 2,4 million households fall into each of these income groups (Martins 2004b:46). The household sizes vary from a low of 3,58 members for the first quintile to a high of 4,16 members for the second quintile with an average of 3,88 for all households. Households falling into the first quintile generally consist of people living in informal houses with no one working in the formal sector. Their average household size of 3,58 is close to the average that is used for calculating the MLL. The data in the rest of the article, except when otherwise mentioned, is taken/calculated from data in Martins (2004b:49, 50, 59, 97-101).

Table 7 shows the percentage distribution of households' annual average expenditure in cash and in kind by income group (Martins, 2004b:49-50). Expenditure in kind is treated as income but also as expenditure and includes all gifts, support other than cash, benefits received and imputed rent (rent that owner-occupied households would get from renting out their property minus compulsory payments).

The expenditure patterns emerging in the table reflect the well-known phenomenon that a poor community spends relatively more of their income on necessities than more affluent communities. Engel's Law, associated with Ernst Engel, stated as early as 1857 that the share of expenditure on food products declines with rising income (Engel, 1895:57).

The Economic Research Service of the United States Department of Agriculture (2003) used 1996 data to analyse nine major consumption groups and eight food subgroups for 114 countries. Countries where more than two-thirds of household budgets are spent on food are as follows: Albania (69,3\%), Armenia $(69,7 \%)$, Azerbaijan (73,5\%), Tajikraton $(68,9 \%)$ and Tanzania $(73,2 \%)$. The countries where the share of food is the lowest of the total household budget are the United States (9,7\%), Hong Kong (10,3\%), Barbados $(11,1 \%)$ and Canada $(11,7 \%)$. The average percentages for South Africa, as shown in Table 7, fall in between the percentages of the two groups of coun-

TABLE 5: GENDER PROFILE OF HOUSEHOLDS AND ANNUAL MINIMUM LIVING LEVEL FOOD BUDGET BY HOUSEHOLD SIZE

\begin{tabular}{|c|c|c|c|}
\hline \multirow{2}{*}{ Household size } & \multicolumn{2}{|c|}{ Percentage (\%) } & \multirow{2}{*}{ MLL food budget } \\
\cline { 2 - 3 } & Male & Female & R5 712 \\
\hline 2 & 48,8 & 51,2 & R8 347 \\
\hline 3 & 46,3 & 53,7 & R10 956 \\
\hline 4 & 46,7 & 53,3 & R13 956 \\
\hline 5 & 46,8 & 53,2 & R16 539 \\
\hline 6 & 46,1 & 53,9 & R19 225 \\
\hline 7 & 46,0 & 51,0 & R24 060 \\
\hline 8 & 45,5 & 54,5 & R12 804 \\
\hline
\end{tabular}

Sources: Martins \& Maritz, 2004:5; Statistics South Africa, 2002: calculated from database 
TABLE 6: INCOME BRACKETS OF QUINTILES AND AVERAGE HOUSEHOLD SIZE BY QUINTILE

\begin{tabular}{|l|l|l|}
\hline \multicolumn{1}{|c|}{ Quintile } & Income brackets & \multicolumn{1}{|c|}{$\begin{array}{c}\text { Average } \\
\text { household } \\
\text { size }\end{array}$} \\
\hline $1^{\text {st }}$ quintile & $<$ R10 639 & 3,58 \\
\hline $2^{\text {nd }}$ quintile & R10 640-R19 509 & 4,16 \\
\hline $3^{\text {rd }}$ quintile & R19 510-R37 112 & 4,14 \\
\hline $4^{\text {th }}$ quintile & R37 113-R80 056 & 3,80 \\
\hline $5^{\text {th }}$ quintile & R80 057+ & 3,70 \\
\hline All households & & 3,88 \\
\hline
\end{tabular}

Source: Martins, 2004(b):46 tries mentioned above. They are also better than many countries from the former Soviet Block that have experienced the shock of falling incomes, increased unemployment, poverty and destitution (Hutton \& Redmond, 2000:1-11). The percentage expenditure of South African households falling into the lowest income group (Table 7 ) on food of $57,1 \%$, is lower than that of 14 out of the 114 countries listed by the Economic Research Service of the United States Department of Agriculture (2003). The number of countries where households spend more than $49,8 \%$ on food, the percentage for the second lowest income group in South Africa, increases to 23 . In general, this analysis shows that many of the poor households in South Africa are still better off than in some other countries due to the fact that they have more discretionary spending options - not all money goes to food. A comparison of the percentage expenditure of the $20 \%$ wealthiest households in South Africa on food with that of other countries shows that there are only four countries where the percentage expenditure on food is lower than $12 \%$, the percentage for South Africa, indicating that a substantial portion of the South African population has money available to spend on luxuries

TABLE 7: PERCENTAGE DISTRIBUTION OF HOUSEHOLD EXPENDITURE IN CASH AND IN KIND BY INCOME AND MAIN EXPENDITURE GROUP, 2004

\begin{tabular}{|c|c|c|c|c|c|c|}
\hline \multirow[t]{2}{*}{ Main expenditure group } & $<$ R10 639 & \begin{tabular}{|c|} 
R10 640 - \\
R19 509 \\
\end{tabular} & $\begin{array}{r}\text { R19 } 510 \text { - } \\
\text { R37 } 112 \\
\end{array}$ & $\begin{array}{c}\text { R37 } 113 \text { - } \\
\text { R80 } 056\end{array}$ & R80 $057+$ & Total \\
\hline & $\%$ & $\%$ & $\%$ & $\%$ & $\%$ & $\%$ \\
\hline Total expenditure & 100,0 & 100,0 & 100,0 & 100,0 & 100,0 & 100,0 \\
\hline Food & 57,1 & 49,8 & 39,4 & 28,0 & 12,9 & 21,0 \\
\hline Housing \& electricity & 6,3 & 9,0 & 12,1 & 15,1 & 18,4 & 16,5 \\
\hline Fuel \& light & 5,8 & 4,4 & 2,6 & 1,0 & 0,3 & 1,0 \\
\hline Personal care & 5,7 & 5,5 & 5,1 & 4,1 & 2,3 & 3,2 \\
\hline Clothing, footwear \& accessories & 5,4 & 6,3 & 6,4 & 5,5 & 2,8 & 3,8 \\
\hline Washing \& cleaning materials, etc & 3,0 & 2,3 & 1,8 & 1,3 & 0,6 & 1,0 \\
\hline Transport & 2,8 & 3,5 & 5,2 & 6,7 & 11,8 & 9,6 \\
\hline Medical \& dental & 0,9 & 1,0 & 1,4 & 2,7 & 4,8 & 3,8 \\
\hline Education & 1,7 & 1,7 & 2,1 & 2,9 & 3,2 & 2,9 \\
\hline Insurance \& funds & 0,9 & 1,0 & 1,7 & 3,6 & 6,0 & 4,8 \\
\hline Recreation, entertainment \& sport & 0,1 & 0,3 & 0,4 & 0,5 & 1,2 & 0,9 \\
\hline Furniture \& household equipment & 1,1 & 1,9 & 2,9 & 3,2 & 3,0 & 2,9 \\
\hline Alcoholic beverages & 2,6 & 3,5 & 4,1 & 4,2 & 2,3 & 2,9 \\
\hline Cigarettes \& tobacco & 2,0 & 2,1 & 2,3 & 2,3 & 1,0 & 1,5 \\
\hline Communication & 0,6 & 1,2 & 1,7 & 2,3 & 2,5 & 2,3 \\
\hline Reading matter \& stationery & 0,1 & 0,2 & 0,5 & 0,8 & 0,7 & 0,7 \\
\hline Holiday/weekend (excl transport) & 0,0 & 0,0 & 0,1 & 0,1 & 0,8 & 0,5 \\
\hline Income tax & 0,0 & 0,2 & 1,3 & 4,2 & 13,0 & 9,4 \\
\hline Miscellaneous & 2,4 & 3,7 & 4,7 & 5,1 & 4,9 & 4,8 \\
\hline Savings & 0,1 & 0,4 & 0,9 & 2,0 & 4,8 & 3,6 \\
\hline Average expenditure & R7 072 & $\mathrm{R} 14793$ & $\mathrm{R} 27245$ & R55 664 & R193 869 & R59 728 \\
\hline
\end{tabular}

Source: Martins, 2004(b):49 
TABLE 8: PERCENTAGE DISTRIBUTION OF HOUSEHOLD EXPENDITURE IN CASH AND IN KIND BY INCOME AND MAIN FOOD GROUP, 2004

\begin{tabular}{|c|c|c|c|c|c|c|}
\hline \multirow[t]{2}{*}{ Main food group } & $<$ R10 639 & $\begin{array}{c}\text { R10 } 640 \text { - } \\
\text { R19 } 509 \\
\end{array}$ & $\begin{array}{c}\text { R19 } 510 \text { - } \\
\text { R37 } 112 \\
\end{array}$ & $\begin{array}{c}\text { R37 113 - } \\
\text { R80 } 056 \\
\end{array}$ & R80 057+ & Total \\
\hline & $\%$ & $\%$ & $\%$ & $\%$ & $\%$ & $\%$ \\
\hline Total expenditure & 100,0 & 100,0 & 100,0 & 100,0 & 100,0 & 100,0 \\
\hline Food in kind & 5,1 & 5,7 & 5,2 & 4,2 & 1,2 & 3,4 \\
\hline Grain products & 36,5 & 31,7 & 26,3 & 21,1 & 16,2 & 22,3 \\
\hline Meat products & 15,1 & 17,7 & 20,7 & 23,2 & 24,1 & 22,0 \\
\hline Fish products & 2,1 & 2,5 & 2,7 & 2,8 & 3,5 & 3,0 \\
\hline Fats \& oils & 3,9 & 3,9 & 3,8 & 3,6 & 3,2 & 3,5 \\
\hline Milk, milk products \& eggs & 6,1 & 7,4 & 8,4 & 8,9 & 9,8 & 8,8 \\
\hline Vegetables & 12,0 & 11,1 & 10,4 & 9,5 & 8,8 & 9,7 \\
\hline Fruit \& nuts & 2,6 & 3,4 & 4,2 & 5,1 & 5,9 & 4,9 \\
\hline Sugar products & 7,8 & 6,2 & 5,1 & 4,3 & 4,0 & 4,8 \\
\hline Nonalcoholic beverages & 5,4 & 5,9 & 6,9 & 7,7 & 8,3 & 7,5 \\
\hline Miscellaneous food & 3,1 & 3,5 & 3,9 & 4,4 & 4,9 & 4,3 \\
\hline Prepared food & 0,4 & 1,0 & 2,4 & 5,1 & 10,0 & 5,8 \\
\hline Average expenditure & $\mathrm{R} 4044$ & R7 356 & R10 740 & R15 564 & R24 924 & R12 540 \\
\hline
\end{tabular}

Source: Martins, 2004(b):59

such as houses, cars, holidays, entertainment, clothes and jewellery.

\section{HOUSEHOLD FOOD BUDGET BY INCOME GROUP}

Average annual expenditure on food in 2004 for the $20 \%$ of South African households falling into the lowest income group is estimated at R4 044. The average monthly food budget for the second income group was R7 356, for the next income group R10 740, for the second last group R15 564 and for the wealthiest $20 \%$ of households R24 924. Table 8 shows the percentage distribution of household expenditure by income and main food group in 2004 (Martins, 2004b:59).

Table 8 shows the following patterns for relative expenditure as income increases (Martins, 2004b:5960):

Growth in percentage expenditure -

- Meat products - from $15,1 \%$ to $24,1 \%$

- Fish products - from $2,1 \%$ to $3,5 \%$

- Milk, milk products and eggs - from $6,1 \%$ to $9,8 \%$

- Fruit and nuts - from $2,6 \%$ to $5,9 \%$

- Nonalcoholic beverages - from $5,4 \%$ to $8,3 \%$

- Prepared food - from $0,4 \%$ to $10,0 \%$

- Miscellaneous food - from $3,1 \%$ to $4,9 \%$

Miscellaneous food includes items such as chutney, pickles, herbs and spices, canned soup, soup powders, potato crisps, cheese curls, salt, pepper and vinegar.
Decline in percentage expenditure -

- Food in kind - from $5,1 \%$ to $1,2 \%$

- Grain products - from $36,5 \%$ to $16,2 \%$

- Fats and oils - from 3,9\% to $3,2 \%$

- Vegetables - from $12,0 \%$ to $8,8 \%$

- Sugar products - from $7,8 \%$ to $4,0 \%$

Attention is given to specific expenditure items falling into the main food groups in the sections that follow.

\section{Grain products}

Households in quintile 5 spend 2,7 times more on grain products than those in quintile 1 . A further breakdown of the figures indicates that almost half $(47 \%)$ the money spent on grain products by the poorest households (quintile 1 ) is spent on mealie or maize meal, a further $18 \%$ on brown bread followed by $11 \%$ on rice. The rich (quintile 5) spend most of their grain budget on white bread (21\%) followed by brown bread $(18 \%)$. Items such as breakfast cereals $(8 \%)$ and pastas $(6 \%)$ feature strongly in quintile 5 household budgets when compared to the other income quintile households.

\section{Meat products}

The wealthiest households' average expenditure of R5 998 on meat products in 2004 is almost ten times more than the R609 of the poorest households. Poultry, including heads and feet, takes up $55 \%$ of the meat budget of the poorest households while expenditure on beef and veal (24\%), poultry (23\%), mutton and lamb (20\%), boerewors (10\%) and processed 
TABLE 9: ANNUAL EXPENDITURE BY FIRST AND FIFTH QUINTILE HOUSEHOLDS ON OTHER MAIN FOOD GROUPS AND ITEMS

\begin{tabular}{|l|c|c|}
\hline \multicolumn{1}{|c|}{ Food group and item } & $\begin{array}{c}\text { First } \\
\text { quintile }\end{array}$ & $\begin{array}{c}\text { Fifth } \\
\text { quintile }\end{array}$ \\
\hline Fish products & R84 & R881 \\
\hline Canned fish & $78 \%$ & $4 \%$ \\
\hline Fresh or chilled fish & $12 \%$ & $36 \%$ \\
\hline Fats and oils & $\mathrm{R} 157$ & $\mathrm{R} 790$ \\
\hline Cooking/salad oil & $69 \%$ & $34 \%$ \\
\hline Fruit and nuts & $\mathrm{R} 105$ & $\mathrm{R} 1482$ \\
\hline Apples & $30 \%$ & $16 \%$ \\
\hline Fruit juices & $7 \%$ & $23 \%$ \\
\hline Sugar products & $\mathrm{R} 314$ & $\mathrm{R} 1006$ \\
\hline White sugar & $85 \%$ & $39 \%$ \\
\hline Non alcoholic beverages & $\mathrm{R} 219$ & $\mathrm{R} 2071$ \\
\hline Tea & $33 \%$ & $9 \%$ \\
\hline Aerated cool drinks & $9 \%$ & $38 \%$ \\
\hline Miscellaneous food & $\mathrm{R} 124$ & $\mathrm{R} 1215$ \\
\hline Canned soup/soup powders & $29 \%$ & $11 \%$ \\
\hline Chutney & $6 \%$ & $24 \%$ \\
\hline Prepared food & $\mathrm{R} 18$ & $\mathrm{R} 2491$ \\
\hline
\end{tabular}

Source: Martins, 2004(b):98-101

meat $(7 \%)$ are the main expenditure items in the meat budget of the wealthiest households.

\section{Milk products and eggs}

As with meat products, households in quintile 5 spent almost ten times more on milk products and eggs than their counterparts in quintile 1. Eggs (28\%), followed by fresh milk (24\%) and milk powder $(16 \%)$ are the main products purchased by the poorest households. One third (33\%) of the high income group expenditure was spent on fresh milk, followed by $15 \%$ on cheese, $14 \%$ on eggs and $9 \%$ on yoghurt.

\section{Vegetables}

The wealthiest households spent an average R2 181 on vegetables in 2004, which is four and a half times more than the R486 that the poorest households spent. Potatoes top the list for both the poorest (34\%) and the wealthiest households (15\%), followed by cabbage (19\%) and tomatoes (16\%) for the poor and by tomatoes $(12 \%)$ and onions $(10 \%)$ for the wealthiest households (calculated from Martins, 2004b:99).

\section{Other main food groups}

Table 9 shows the expenditure by the first and fifth quintile households on other main food groups as well as the major food items on which households spent their money in 2004 (calculated from Martins, 2004b:98-101).
Table 9 shows, for instance, that quintile 1 households spent R84 on fish products and quintile 5 households R881 on average in 2004. Canned fish tops the list under fish products for the poorest households $(78 \%$ of the R84 expenditure on fish products) while fresh and chilled fish were the major fish products that the wealthiest households bought in 2004 (36\% of the R881). The biggest difference in expenditure per household is for prepared food where the wealthiest households spent 138 times more than the poorest households.

\section{SUMMARY AND CONCLUSION}

The minimum financial requirements of an average family living in one of the major urban areas of South Africa for food in 2004 was R1 067 per month or R12 804 for the year. The amount of R12 804 can serve as a benchmark for comparing actual expenditure of an average household (3,60 members) on food to determine whether they have enough money available to adhere to this minimum, which can be considered a poverty datum line. The total average household budget in 2004 of the $20 \%$ poorest households (average household size 3,58) was R7 072 (calculated from Martins, 2004b:48) and their food budget was R4 040 (calculated from Martins, 2004b:58). The R4 040 is even lower than the MLL food budget of R5 712 for a household of two persons (see Table 5), suggesting a considerable number of households in South Africa that live in absolute poverty. Some households falling into quintiles 2 and 3, whose household sizes are larger than that of quintile 1 households will also have less than that which is set as a minimum food budget. However, to calculate what percentage of South Africa lives in poverty, family size and structure as well as own produce of food in the rural areas must be taken into account.

Considerable differences prevail between the expenditure patterns of the rich and the poor. Poor households spend most of their money on grain products, notably mealie meal and brown bread, and poultry. Price movements of these products will impact heavily on the well-being of these people and must be kept under control as far as possible. Policy decisions on food, such as food enrichment, must also take into account the foodstuffs mostly bought by the poor.

The wealthiest households, who are usually the better educated sector of society spend their money on a wide variety of foodstuffs. The size of their food budget of almost R25 000 in 2004 may allow them to follow a well-balanced diet depending on the choices they make regarding the nutritional value of food items selected and purchased.

\section{REFERENCES}

BOK, D. 2001. The trouble with government. Cambridge. Harvard University Press.

DEPARTMENT OF NATIONAL HEALTH AND POPULATION DEVELOPMENT. 1994. Household ration 
scale 1 for very low-cost meals. Pretoria ECONOMIC RESEARCH SERVICE:

UNITED STATES DEPARTMENT OF AGRICULTURE. 2003. International food consumption patterns. Available on line. URL: http://www.ers.usda.gov/data/InternationalFoodDemand/. Accessed February 2005.

ENGEL, E. 1895. Die Lebenskosten belgischer Arbeiterfamilien frueher und jetzt. Ermittelt aus Familienhaushaltsrechnungen und vergleichend zusammengestellt. Bulletin of the International Institute of Statistics, 9:57ff

HUTTON, S \& REDMOND, G. 2000. Poverty in transition economies. London. Routledge.

MARTINS, JH. 2002. Income and expenditure patterns of households in the Cape Peninsula, 2001. Pretoria. University of South Africa, Bureau of Market Research. Report 300.

MARTINS, JH. 2003. Income and expenditure patterns of households in the Durban metropolitan area, 2002. Pretoria. University of South Africa, Bureau of Market Research. Report 316.

MARTINS, JH. 2004a. Income and expenditure patterns of households in Gauteng, 2003. Pretoria. University of South Africa, Bureau of Market Research. Report 327.

MARTINS, JH. 2004b. Total household expenditure in South Africa by income group, life plane, life stage and product, 2004. Pretoria. University of South Africa, Bureau of Market Research. Report 326.

MARTINS, JH \& MARITZ, ME. 2004. Minimum and supplemented living levels in the main and other selected urban areas of the RSA, March 2004. Pretoria. University of South Africa, Bureau of Market Research. Report 334

NATIONAL ACADEMY OF SCIENCES. 1968. Recommended dietary allowances. 7th edition. Washington DC.

SAUNDERS, P. 2004. Updated budget standard estimates for Australian working families in September 2003. Sydney. University of New South Wales, Social Policy Research Centre. Report 1/04.

STATISTICS SOUTH AFRICA. 2002. Raw income and expenditure data for 2000 supplied to BMR. Pretoria.

STATISTICS SOUTH AFRICA. 2003. Census 2001. Census in brief. Pretoria.

TALAL, BB. 2000. Investing in the rural poor: $A$ challenge for the $21^{\text {st }}$ century. New York. United Nations. (UN Chronicle 3.)

UNITED NATIONS DEVELOPMENT PROGRAMME. 2000. United Nations Development Programme poverty report: Overcoming human poverty. New York. UNDP. 